Добіжа Наталія Володимирівна доктор економічних наук, доцент, професор кафедри фінансів банківської справи та страхування, Вінницький навчально-науковий інститут економіки Західноукраїнського національного університету, вул. Гонти, 37, м. Вінниця, 21017, тел.: (0432) 55-49-55, e-mail: natalle.dobizha@gmail.com, https://orcid.org/0000-0002$8277-7977$

Мирончук Вікторія Михайлівна кандидат економічних наук, доцент кафедри фінансів банківської справи та страхування, Вінницький навчальнонауковий інститут економіки Західноукраїнського національного університету, вул. Гонти, 37, м. Вінниця, 21017, тел.: (0432) 55-49-55, e-mail: viktoriia.myronchuk@gmail.com, https://orcid.org/0000-0002-1720-4558

Виганяйло Світлана Миколаївна кандидат економічних наук, доцент кафедри соціально-економічних дисциплін, Сумська філія Харківського національного університету внутрішніх справ, вул. Миру, 24, м. Суми, 40007, тел.: (0542) 33-03-18, e-mail: vyganyaylosvitlana@ukr.net, https://orcid.org/00000001-5350-0728

\title{
ЗАБЕЗПЕЧЕННЯ ЕКОНОМІЧНОЇ БЕЗПЕКИ ДЕРЖАВИ В ПРОЦЕСІ СТРАХУВАННЯ
}

Анотація. У статті досліджується проблематика забезпечення економічної безпеки держави в процесі страхування. Економіка держави $\epsilon$ системним інститутом, а відповідно мінливим до впливу різноманітних факторів. Враховуючи світові тенденції у сфері страхування, необхідність підвищення ролі страхового ринку в забезпеченні економічної безпеки України, НБУ формує основні заходи для пожвавлення цього сектора на основі вимог ЄС. Останні спрямовані на посилення захисту фізичних та юридичних осіб - споживачів страхових послуг, підвищенні фінансової стійкості страхових компаній, формування моделі управління страховими операціями на основі ризиків та застосування пруденційного нагляду, визначення зміни організаційно-правової форми організації страхового бізнесу. У статті досліджено правове регулювання, 
яке визначає політику та основні шляхи розвитку сфери страхування та забезпечення економічної безпеки держави в процесі страхування. Визначено основні складові економічної безпеки держави. З'ясовано основні фактори, які впливають на розвиток страхування, на їх фінансову складову. Визначено зв'язок між фінансовою безпекою громадян, суспільства, бізнесу 3 економічною безпекою держави. Доведено, що позитивний інвестиційний клімат держави позитивно впливає на розвиток та безпеку економіки, відповідно інвестиційна політика страхових компаній забезпечить стабільність інституту, довіру громадян та економічну безпеку держави. У статті встановлено основні причини зовнішніх загроз фінансовій безпеці страхового ринку. Виокремлено найбільші загрози економічній безпеці банківських установ і страхових компаній. Проаналізовано основні показники діяльності страхового ринку України та його динаміку. Встановлено види страхування, які мають найбільше значення в системі забезпечення економічної безпеки держави. Доведено, що формування системи забезпечення економічної безпеки вимагає врахування як об’єктивних, так i суб’єктивних факторів.

Ключові слова: фінансові ресурси, фінансова безпека, страховий ринок, страхова діяльність, небанківський фінансовий сектор.

Dobizha Nataliia Volodymyrivna Doctor of Economics, Associate Professor, Professor at the Department of Banking Finance and Insurance, Vinnytsia Educational and Research Institute of Economics, West Ukrainian National University, Honty St., 37, Vinnytsia, 21017, tel.: (0432) 55-49-55, e-mail: natalle.dobizha@gmail.com, https://orcid.org/0000-0002-8277-7977

Myronchuk Viltoriia Mykhailivna Candidate of Economic Sciences (Ph.D.), Associate Professor at the Department of Banking Finance and Insurance, Vinnytsia Educational and Research Institute of Economics, West Ukrainian National University, Honty St., 37, Vinnytsia, 21017, tel.: (0432) 55-49-55, e-mail: viktoriia.myronchuk@gmail.com, https://orcid.org/0000-0002-1720-4558

Vyhaniailo Svitlana Mykolaivna Candidate of Economic Sciences (Ph.D.), Associate Professor at the Department of Socio-Economic Disciplines, Kharkiv National University of Internal Affairs Sumy Branch, Sumy, 40007, Peace St., 24, tel.: (0542) 33-03-18, e-mail: vyganyaylosvitlana@ukr.net, https://orcid.org/0000-00015350-0728 


\title{
PROVISION OF THE STATE'S ECONOMIC SECURITY IN THE INSURANCE PROCESS
}

\begin{abstract}
The article examines the issue of ensuring the economic security of the state in the insurance process. The economy of the state is a systemic institution, and accordingly variable to the influence of various factors. Given the global trends in the field of insurance, the need to increase the role of the insurance market in ensuring the economic security of Ukraine, the NBU forms the main measures to revive this sector based on EU requirements. The latter are aimed at strengthening the protection of individuals and legal entities - consumers of insurance services, increasing the financial stability of insurance companies, forming a model of management of insurance operations based on risks and application of prudential supervision, determining changes in organizational and legal form of insurance business. The article examines the legal regulation, which determines the policy and main ways of development of insurance and ensuring the economic security of the state in the insurance process. The main components of economic security of the state are determined. The main factors influencing the development of insurance, their financial component are clarified. The connection between financial security of citizens, society, business with economic security of the state is determined. It is proved that the positive investment climate of the state has a positive effect on the development and security of the economy, respectively, the investment policy of insurance companies will ensure the stability of the institution, public confidence and economic security of the state. The article identifies the main causes of external threats to the financial security of the insurance market. The biggest threats to the economic security of banking institutions and insurance companies have been identified. The main indicators of the insurance market of Ukraine and its dynamics are analyzed. The types of insurance that are most important in the system of economic security of the state have been identified. It is proved that the formation of a system of economic security requires taking into account both objective and subjective factors.
\end{abstract}

Keywords: financial resources, financial security, insurance market, insurance activity, non-banking financial sector.

Постановка проблеми. Економічна безпека держави є важливою складовою національної безпеки. Страхування слугує інструментом оптимізації фінансових ресурсів, які забезпечують досягнення економічної безпеки держави, оскільки формується раціональна їх структура задля здійснення відповідних превентивних, оперативних та стратегічних заходів для запобігання (або оперативного усунення) наслідкам дії негативних факторів.

Маневрування фінансовими ресурсами формує базис економічної безпеки 
держави. Доцільність та актуальність підтримання фінансової безпеки як складової економічної безпеки держави пов’язана з тим, що встановлення захисту інтересів споживачів страхового ринку неможливе без ефективного його функціонування. Проте, це стає реальним лише за умов ефективного здійснення страхової справи, умови розвитку якої створює держава.

Аналіз останніх досліджень і публікацій. Науковою базою дослідження стали роботи вітчизняних та зарубіжних науковців, що досліджують стан економічної безпеки держави, надання страхових послуг, розвиток ринку страхування, вплив процесу страхування на економічну безпеку держави.

Так, серед науковців, які досліджували теоретичну частину фінансової безпеки України та їі загрози є: Гладчук О.М., Фролов С.М., Козьменко О.В., Бойко А.О., Барановський О.I. Фактори впливу на фінансову та економічну безпеку досліджували: Яремик М.М., Приказюк Н., Моташко Т., Фурман В.М. Стан страхового ринку та його вплив на економічну безпеку держави досліджували: Сокол С.В., Русецька Е. А., Арустамова В. А., Аксененко С. В., Русецький М. Г. Дахнова О. Є. досліджувала соціальні аспекти економічної безпеки України.

Мета статті полягає у дослідженні стану забезпечення економічної безпеки держави в процесі страхування та виокремленні факторів впливу на фінансову безпеку страхового ринку.

Виклад основного матеріалу. Політика та шляхи забезпечення економічної безпеки держави в процесі страхування визначається нормативно-правовими актами зазначеними в Таблиці 1.

Таблиця 1.

\section{Правове регулювання забезпечення економічної безпеки держави в} процесі страхування.

\begin{tabular}{|c|c|}
\hline $\begin{array}{l}\text { Концепції запровадження пруденційного } \\
\text { нагляду за небанківськими фінансовими } \\
\text { установами та Програми розвитку системи } \\
\text { пруденційного нагляду за небанківськими } \\
\text { фінансовими установами, затверджені } \\
\text { розпорядженням Державної комісії } 3 \\
\text { регулювання фінпослуг України від 15.07.2010 } \\
\text { р. №585 }\end{array}$ & $\begin{array}{l}\text { визначено вимоги до здійснення страхової } \\
\text { діяльності задля державного нагляду. }\end{array}$ \\
\hline $\begin{array}{l}\text { Концепції забезпечення національної безпеки } \\
\text { у фінансовій } \quad \text { сфері, затвердженої } \\
\text { розпорядженням КМУ від } 15.08 .2012 \text { р. № } \\
\text { 569-р }\end{array}$ & $\begin{array}{llr}\text { сформовано } & \text { основні напрями державної } \\
\text { політики у у сфері } \\
\text { фінансового сектору. }\end{array}$ \\
\hline
\end{tabular}




\begin{tabular}{|c|c|}
\hline $\begin{array}{l}\text { Стратегії розвитку фінансового } е \text { сектору } \\
\text { України до } 2025 \text { року, яка затверджена } \\
\text { рішенням Національної комісії } 3 \text { цінних } \\
\text { паперів та фондового ринку від } 27.12 .2019 \text { р. } \\
\text { № } 797\end{array}$ & $\begin{array}{l}\text { визначена основна } \\
\text { страхування в Україні та створена система } \\
\text { заходів до пї вирішення, зокрема щодо } \\
\text { розвитку ринку страхових послуг, його } \\
\text { фінансової стабільності, сприяння } \\
\text { функціонування, забезпечення розвитку } \\
\text { SupTech\&RegTech та цифрової економіки. }\end{array}$ \\
\hline $\begin{array}{l}\text { Національної економічної стратегії на період } \\
\text { до } 2030 \text { року, затвердженої постановою КМУ } \\
\text { від 03.03.2021 р. № } 179\end{array}$ & $\begin{array}{l}\text { ринок страхування в Україні недостатньо } \\
\text { розвинутий як за рівнем споживання } \\
\text { страхових послуг, так і за обсягом активів } \\
\text { страхових компаній. Тому, вважаючи } \\
\text { страхування важливою ланкою фінансової } \\
\text { безпеки держави, визначено необхідність } \\
\text { забезпечення розвитку усіх елементів } \\
\text { фінансового сектору країни забезпечення } \\
\text { розвитку ринку страхових послуг. }\end{array}$ \\
\hline $\begin{array}{l}\text { Стратегії економічної безпеки України на } \\
\text { період до } 2025 \text { року, яка затверджена } \\
\text { рішенням Ради національної безпеки і оборони } \\
\text { України від } 11.08 .2021 \text { р. }\end{array}$ & 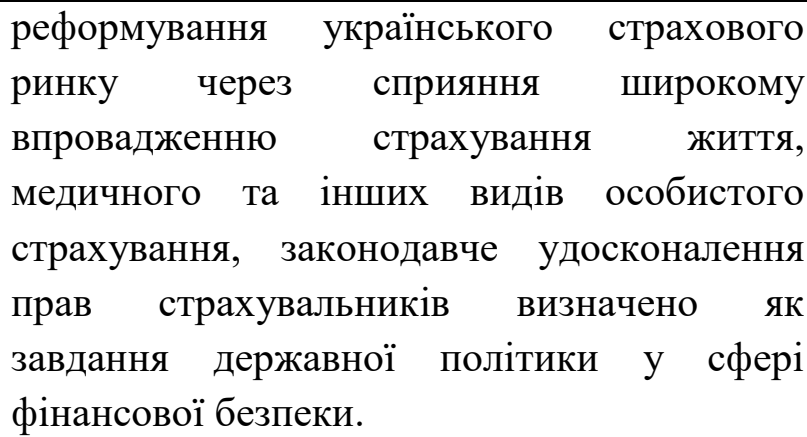 \\
\hline
\end{tabular}

Джерело: розробка автора.

Забезпечення економічної безпеки країни безпосередньо пов'язане 3 ефективністю іiї економіки, тобто економічна система країни поряд із захисними заходами, здійснюваними державою, повинна бути захищена на основі високої продуктивності праці, якості продукції тощо. Тому економічна безпека країни не може бути функцією якого-небудь одного державного відомства, служби. Вона підтримується всією системою державних органів, всіма ланками і структурами економіки.

Економічні загрози в системі страхування є реальною загрозою економічній безпеці держави. Зокрема, економічна злочинність спричиняе зростання цін в системі страхування: чим вищий рівень шахрайства, тим більше нецільових витрат змушений терпіти страховик, і тим вище (в силу необхідності компенсувати ці понаднормові видатки) вартість страхових послуг. Від даного негативного ефекту страждають, перш за все, сумлінні і законослухняні страхувальники, чиї страхові внески поза їх волі незаконно розподіляються між злочинцями, а страхові активи зазнають позапланових і слабо регульованих витрат на покриття незаконних виплат та вимушених витрат на врегулювання 
юридично необгрунтованих збитків. Злочинність в страхуванні дестабілізує соціально-економічний розвиток суспільства, дискредитує принципи страхування, знижує податкові внески страхового сектора в бюджет країни та ії інвестиційні внески в економічні інститути, загалом, загрожує всім сегментам суспільства та іï економічній безпеці [1], [2].

Страховий ринок потребує системного адекватного самозахисту від операційних загроз, оскільки є високий рівень ймовірності банкрутства страхових компаній. Тому, перш за все, необхідно визнати, що збереження активів страхових компаній відноситься до питань національної безпеки.

Держава має забезпечити повноцінну конкуренцію у всіх секторах страхування, оскільки іiі недостатній рівень слугує найважливішою причиною економічної злочинності, адже конкуренція здійснюється за відомими ринку і прозорими правилами гри. Особливі умови функціонування страхової компанії це вихід за межі загальноприйнятих правил, це робота не на суспільство, а на корпоративні інтереси на шкоду інтересам суспільства і держави.

Перешкодою до здійснення конкурентних відносин в страховому секторі можуть бути відносини між банками - страховиками - клієнтами, сутність яких полягає в тому, що позичальнику банку в добровільно-примусовому порядку нав'язують певні умови страхування (включаючи необхідність страхування життя i здоров'я) i надають визначений перелік страхових компаній, де можна застрахувати свої ризики. Подібна практика обмежує права позичальників і підвищує їх витрати при кредитуванні. Крім того, вона обмежує права дрібних страхових компаній, фактично перекриваючи їм доступ на ринок.

Покращення інвестиційної політики страхових компаній вимагає покращення інвестиційних гарантій, ділового середовища, забезпечення прав власності, а також розвитку відповідних інструментів інвестування, які відповідають вимогам страховиків з точки зору диверсифікації, зворотності, прибутковості і ліквідності інвестиційного капіталу. Макрозавданням страхової спільноти є формування атмосфери довіри у населення до ділового життя країни, в зростанні практичного інтересу до страхування, до створення системи стимулів для розвитку довгострокового страхування життя, включаючи пенсійне страхування. До тих пір, поки страхування життя в Україні не стане інструментом накопичення, інвестиційний потенціал страхового сектора залишиться невисоким як у відносному (у порівнянні 3 іншими інститутами інвестицій), так і в абсолютному (в масштабах сукупних інвестицій в економіку країни) значеннях.

Н. Приказюк, Т. Моташко також стверджують, що без ефективного функціонування страхового ринку неможливо створити ефективну систему захисту громадян, підприємців, бізнесу, держави та підтримати соціальну 
стабільність. Розвиток усіх галузей національної економіки залежить від надійного розвитку страхового ринку та фінансової підтримки страхових компаній. Вони відзначають, що страхові ринки розвинених країн характеризуються високим рівнем безпеки, а в Україні - страховий ринок знаходиться на стадії розвитку. Лише за побудови ефективних взаємовідносин та взаємодії між громадянами, бізнесом, страховими посередниками, державою страховий ринок досягне фінансово безпечного рівня свого розвитку. Тобто страховий ринок тоді знаходиться у фінансово безпечному стані, коли фінансові інтереси страхових компаній у певній мірі узгоджені 3 інтересами інших суб'єктів - страхувальників, кредиторів, конкурентів, держави, позичальників, інвесторів та ін., що сприяє мінімізації зовнішнього впливу загроз на загальний рівень фінансової безпеки ринку страхових послуг [3].

Так, на макрорівні страхування як економічний механізм передачі ризиків забезпечує стабільність національної економіки перед зовнішніми потрясіннями та дозволяє нейтралізувати руйнівну дію дестабілізуючих факторів. Слід зазначити, що крім основних видів діяльності (страхування) страхові компанії $є$ активними інституційними інвесторами. Накопичуючи значну суму доходу від страхових премій, вони можуть суттєво вплинути на формування інвестиційного попиту в країні та перерозподіл фінансових ресурсів між галузями, секторами економіки та окремими суб’єктами господарювання. Отже, страховики впливають на іншу складову фінансової безпеки держави - безпеку інвестиційного сектору. Через створення спеціалізованих страхових фондів i формування страхового покриття відповідних ризиків страхові компанії вагомі у забезпеченні фінансової безпеки держави [4, С.300].

Відповідно до Методичних рекомендацій щодо розрахунку рівня економічної безпеки України, затверджених наказом Міністерства економічного розвитку і торгівлі України від 29.10.2013 № 1277, складовими економічної безпеки $\epsilon$ : демографічна, виробнича, інвестиційно-інноваційна, енергетична, зовнішньоекономічна, продовольча, макроекономічна, соціальна, фінансова безпеки. У свою чергу, до системи фінансової безпеки відносять й безпеку небанківського фінансового сектору, який характеризує рівень розвитку фондового та страхового ринків, що дає змогу повною мірою задовольняти потреби суспільства в зазначених фінансових інструментах та послугах (рис. 1). Проте відзначимо, що на відміну від Методики розрахунку рівня економічної безпеки України, затвердженої у 2007 році, поняття «безпека страхового ринку» взагалі не виокремлюється (обчислюється лише безпека небанківського фінансового сектору), що $\epsilon$, на нашу думку, невиправданим, оскільки саме страхування визначає рівень безпеки інших галузей національного господарства та створює передумови для ефективного розвитку економіки в цілому. 


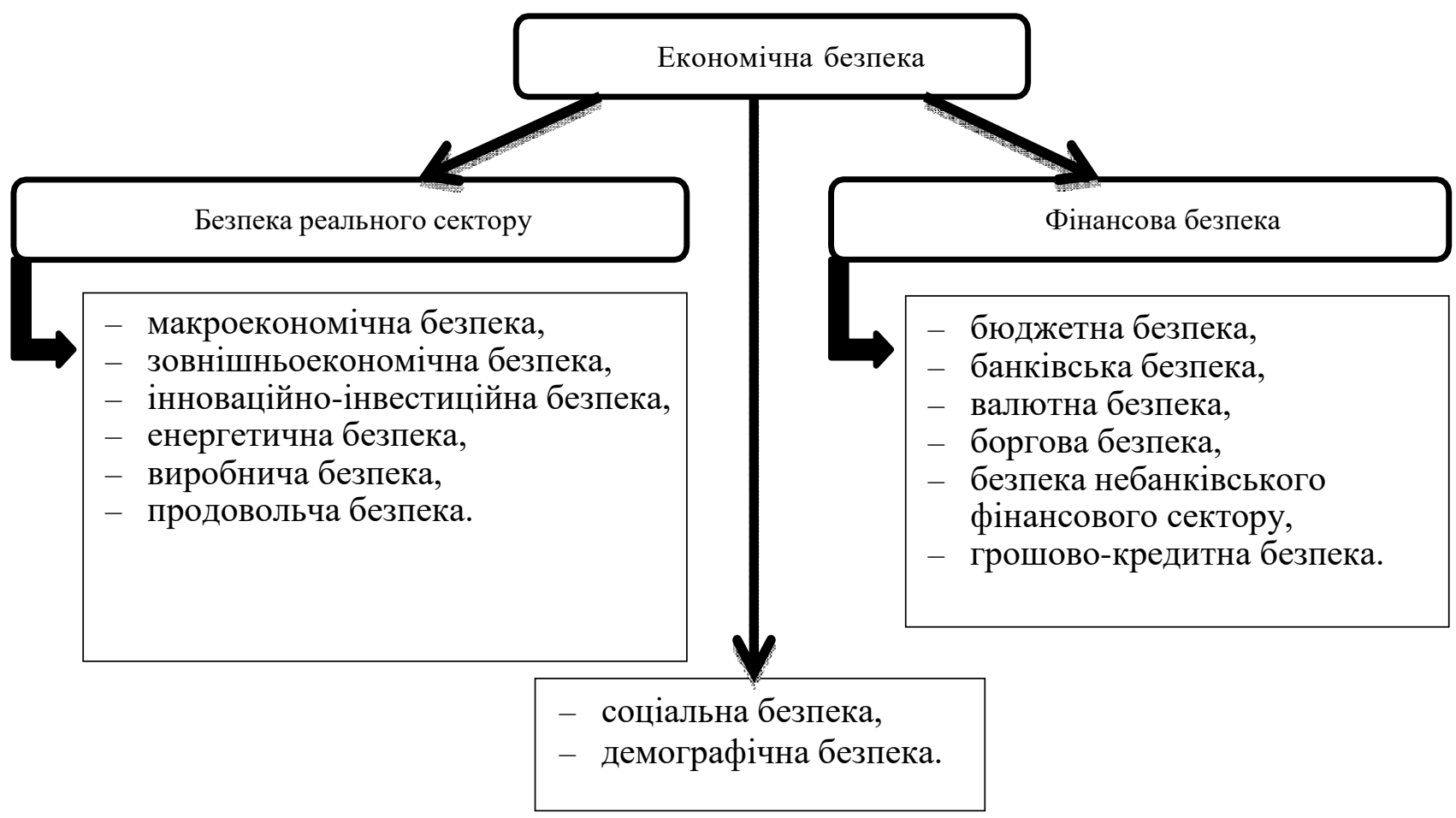

Pис. 1. Складові економічної безпеки держави Джерело: уточнено автором за[5].

O.I. Барановський, під фінансовою безпекою ринку страхових послуг загалом і конкретного страховика розуміє такий рівень забезпеченості страхових компаній фінансовими ресурсами, який дозволив би їм у разі потреби відшкодовувати обумовлені у договорах страхування збитки їх клієнтів i забезпечити ефективне функціонування компанії [6, С.325]. Досить вдалу та повну систематизацію таких факторів запропоновано саме О. Барановським ще у 2004 році, серед основних причин зовнішніх загроз фінансовій безпеці страхового ринку він виділяє наступні: швидкий розвиток глобалізації; високий ступінь концентрації фінансових ресурсів на міжнародних страхових ринках та інтеграція у сфері перестрахування; збільшена автономія субдержавних суб'єктів; високий ступінь мобільності та взаємозв'язку страхових фінансових ринків на основі нових інформаційних технологій; взаємопроникнення внутрішньої та зовнішньої політики, яка все більше залежить від глобального фінансового страхування; посилення конкуренції та конфліктів між державами у секторі страхування; надмірна залежність національних галузей страхування (особливо у сфері перестрахування) на іноземний капітал, що робить фінансову безпеку страхування особливо вразливою та глобальне зростання нестабільності у страховій складовій світової фінансової системи, поява загрозливих кризових тенденцій, нездатність сучасних фінансових установ (у тому числі міжнародних) ефективно контролювати їх [7, С.232]. 
С.В. Сокол пропонує перелік внутрішніх та зовнішніх загроз фінансовій безпеці страхового ринку. При цьому, подані загрози здебільшого властиві як діяльності не лише для страхового ринку, а й для його учасників - страхових компаній [8, С. 290].

Так, В. М. Фурман, Н. В. Зачосова вважають, що найважливішим у цьому питанні $є$ формування збалансованих страхових та кредитних портфелів. Також ними відзначений суттєвий взаємозв'язок між банківською системою та ринком страхових послуг як у формуванні фінансових ресурсів, так і ймовірності банкрутства у випадках проблемної роботи банківської системи. Вони вказують на те, що більшість страхових компаній в Україні працюють за принципом фінансової піраміди, адже відшкодування власних витрат здійснюється за рахунок нових страхових премій та надходжень [9, С.9].

Отже, дослідники до найбільших загроз економічній безпеці банківських установ і страхових компаній відносять: загальний економічний спад; девальвацію національної валюти; нестійкість та непередбачуваність валютних курсів; дефіцит ліквідності; втрату ділової репутації; втрату клієнтів та їх довіри до установ і компаній; вилучення фінансових активів зі збереження і управління; зниження попиту на фінансові послуги; низький рівень регулятивного i резервного капіталів; падіння доходів населення і його нездатність виконувати свої фінансові зобов'язання; скорочення кредитних та інших видів фінансових операцій; неефективність фінансового менеджменту; шахрайство; політичну нестабільність; військові дії у державі; активізацію рейдерських атак; недоліки в організації державного регулювання і нагляду [9, С.10].

Русецка Е.А. виокремила види страхування, які мають найбільше значення в системі забезпечення економічної безпеки держави: обов'язкове медичне страхування; добровільне медичне страхування; страхування від нещасних випадків; страхування життя; обов'язкове особисте страхування; страхування професійної відповідальності; страхування відповідальності підприємств джерел підвищеної небезпеки; страхування майна юридичних і фізичних осіб; страхування будівельно-монтажних ризиків тощо [10].

За даними Білої книги «Майбутнє регулювання ринку страхування в Україні» та Національної економічної стратегії на період до 2030 року, страховий ринок України є незначним за обсягом активів та за рівнем споживання страхових послуг. Так, показник проникнення страхових послуг в Україні, що обчислюється як співвідношення обсягу залучених страхових премій до ВВП, становить 1,4 \%, при тому, що показник у більшості інших країн регіону $\epsilon$ 
вищим, а середній показник у державах - членах СС дорівнює 5\%, в середньому у світі - 6,1\%. Лідерами за цим показником страхування у світі $є$ Великобританія, Японія та Франція. Окрім цього, показник щільності страхування як розмір страхової премії на одну особу, в Україні він перебуває на дуже низькому рівні і на кінець 2018 року становив 34 дол. США. 3-поміж 88 країн, які досліджував Swiss Re Institute, Україна за цими показниками споживання послуг загального («non-life») страхування посідає 73 місце та послуг страхування життя 82 місце [11]. За таких низьких значень показників страхування не може впливати на економіку і не відіграє значної ролі в соціально-економічних відносинах держави. Україна протягом тривалого часу зберігає низьку купівельну спроможність потенційних страхувальників та відсутність ефективного попиту на страхові послуги. Поширеність страхових послуг в Україні $є$ недостатнім та визначається низькою страховою культурою українського населення, яке, на відміну від жителів розвинених країн, не розглядає страхування як ефективний механізм боротьби з ризиками. Як результат, значна частка ризиків, 3 якими стикаються громадяни та юридичні особи, не застрахована. Крім того, така ситуація зменшує здатність страхового ринку забезпечувати національну економіку необхідними інвестиційними ресурсами, зменшувати навантаження на державний бюджет України.

Початковим критерієм оцінки стану страхового ринку (табл.2) є кількість страхових компаній та розмір активів страховиків. Ринок страхових послуг $\epsilon$ другим за рівнем капіталізації серед інших небанківських фінансових ринків. Аналізуючи Таблицю 2 встановлено, що при зменшенні кількості страхових компаній та їх сплачених статутних капіталів у 2019 р. відповідно на 17,1\% та 12,4\% показники діяльності страхових компаній стабільно зростають, - так, валові страхові премії зросли у 2019 році на 7,4 \% у порівнянні з 2018 роком, страхові резерви та валові страхові виплати відповідно збільшились на 9,6\% та 11,5\%. У порівнянні I кварталу 2019 року з І кварталом 2020 року темпи приросту всіх показників зменшились, окрім валових страхових виплат, які зросли на 13,2\%. Кількість страхових компаній значно скоротилася. Такі зміни кількості страхових компаній свідчать про незначні якісні зміни на ринку. Страхові компанії, що припинили діяльність на ринку, виявилися менш конкурентоспроможними, нездатними відповідати за взяті на себе зобов'язання та надавати якісні страхові послуги. Дана ситуація загалом свідчить про оздоровлення ринку за рахунок ліквідації малоефективних компаній. 
Табличя 2.

\section{Основні показники діяльності страхового ринку України та його динаміка}

\begin{tabular}{|c|c|c|c|c|c|c|}
\hline \multirow{3}{*}{ Показники } & \multirow{3}{*}{2017} & \multirow{3}{*}{2018} & \multirow{3}{*}{2019} & \multicolumn{3}{|c|}{ Темпи приросту } \\
\hline & & & & $\begin{array}{c}2018 / \\
2017\end{array}$ & $\begin{array}{r}2019 / \\
2018\end{array}$ & \begin{tabular}{c|} 
I кв. \\
$2020 /$ \\
I Кв. \\
2019
\end{tabular} \\
\hline & & & & \multicolumn{3}{|c|}{$\%$} \\
\hline $\begin{array}{l}\text { Кількість договорів, } \text { крім } \\
\text { договорів } 3 \text { обов’язкового } \\
\text { страхування від нещасних } \\
\text { випадків на транспорті }\end{array}$ & 70658,2 & 77495,0 & 80271,1 & 9,7 & 3,6 & $-6,9$ \\
\hline $\begin{array}{lr}\text { Кількість } & \text { договорів } \\
\text { обов’язкового } & \text { особистого } \\
\text { страхування } & \text { від } \\
\text { випадків на транспорті }\end{array}$ & 114824,7 & 123582,5 & 116652,6 & 7,6 & $-5,6$ & $-15,6$ \\
\hline Кількість страхових компаній & 294 & 281 & 233 & $-4,4$ & $-17,1$ & $-15,1$ \\
\hline Валові страхові премії & 43431,8 & 49367,5 & 53001,2 & 13,7 & 7,4 & $-13,4$ \\
\hline Валові страхові виплати & 10536,8 & 12863,4 & 14338,3 & 22,1 & 11,5 & 13,2 \\
\hline
\end{tabular}

Джерело: Нацкомфінпослуг.

Протягом 2018-2019 років зростає кількість укладених договорів страхування на 3,6\%, а у порівнянні I кварталу 2019 року з I кварталом 2020 року кількість договорів скоротилася на 6,9\%.

Це свідчить про загальну нерозвиненість вітчизняного страхового ринку та низьку готовність громадян страхувати існуючі ризики. У свою чергу, низька готовність страхувати ризики обумовлена як низькими доходами громадян, так і рівнем фінансової культури, а також патерналістськими настроями. Окрім цього, пандемія Covid-19 є негативним фактором впливу на розвиток страхового ринку.

Аналізуючи Таблицю 3 можемо зробити висновок, що лідером по виплатам $\epsilon$ галузь добровільного особистого страхування. Також значимими сегментами за страховими виплатами є недержавне обов'язкове страхування та добровільне майнове страхування.

Таблиия 3.

Рівень страхових виплат за видами страхування.

\begin{tabular}{|l|c|c|c|c|}
\hline \multirow{2}{*}{ Види страхування } & \multicolumn{4}{|c|}{ Рівень валових страхових виплат, } \\
\cline { 2 - 5 } & $\begin{array}{l}\text { Станом на } \\
31.12 .2018\end{array}$ & $\begin{array}{l}\text { Станом на } \\
31.12 .2019\end{array}$ & $\begin{array}{l}\text { Станом на } \\
\text { I квартал } \\
2019\end{array}$ & $\begin{array}{l}\text { Станом на } \\
\text { I квартал } \\
2020\end{array}$ \\
\hline Страхування життя & 18,0 & 12,5 & 4,4 & 3,9 \\
\hline
\end{tabular}




\begin{tabular}{|l|c|c|c|c|}
\hline $\begin{array}{l}\text { Види страхування, інші, ніж } \\
\text { страхування життя, у тому } \\
\text { числі: }\end{array}$ & 26,7 & 28,4 & 95,6 & 96,1 \\
\hline Добровільне особисте страхування & 37,2 & 36,1 & 24,8 & 25,2 \\
\hline Добровільне майнове страхування & 24,2 & 24,6 & 47,0 & 43,6 \\
\hline $\begin{array}{l}\text { - в тому числі страхування } \\
\text { фінансових ризиків }\end{array}$ & 30,9 & 36,9 & 12,5 & 10,3 \\
\hline $\begin{array}{l}\text { Добровільне страхування } \\
\text { відповідальності }\end{array}$ & 2,5 & 12,4 & 1,5 & 0,8 \\
\hline $\begin{array}{l}\text { Недержавне обов'язкове } \\
\text { страхування }\end{array}$ & 36,2 & 39,0 & 22,3 & 26,5 \\
\hline $\begin{array}{l}\text { - в тому числі страхування } \\
\text { цивільної відповідальності } \\
\text { власників транспортних засобів }\end{array}$ & 44,7 & 45,0 & 21,4 & 22,9 \\
\hline
\end{tabular}

Джерело: Начкомфінпослуг

В Україні майнове страхування $\epsilon$ більш популярним, ніж особисте страхування. Більше того, можна говорити про загальну низьку готовність українців страхувати ризики: як у порівнянні 3 розвиненими країнами, так $\mathrm{i}$ країнами, що розвиваються. Це спричинено низькими доходами громадян та рівнем фінансової культури, а також, що важливо, патерналістичними настроями. Більшу популярність майнових ризиків у порівнянні з особистими можна також пояснити патерналізмом, який формується, серед іншого, існуючою системою обов'язкового медичного страхування. Однак висока диференціація доходів населення також $\epsilon$ важливим фактором. Заможні громадяни, які можуть собі забезпечити страхування, володіють великими обсягами майна. Відповідно, й більшою $\epsilon$ кількість укладених договорів щодо ризиків власності порівняно 3 особистими. Крім того, більш заможні люди мають більш вищу якість життя (харчування тощо), що знижує захворюваність, смертність та збільшує тривалість життя. I ця категорія громадян здатна вирішувати проблеми зі здоров'ям за допомогою приватної медицини.

Загалом поведінку українців у багатьох аспектах можна визнати ірраціональною. Перш за все, населення намагається забезпечити собі відчуття безпеки, але не зменшити можливі фінансові втрати: зв'язок між часткою внесків та сумою платежів практично відсутня. Отже, формування системи забезпечення економічної безпеки вимагає врахування як об'єктивних факторів (рівень доходів, обсяг власності, тривалість життя тощо), так і суб'єктивних факторів (наприклад, стать), які впливають на сприйняття ризику індивідами. Більша готовність страхувати майно, а неособисті ризики, спричиняє необхідність, 3 одного боку, звертати увагу на заходи забезпечення онтологічної безпеки щодо 
майнових ризиків для появи почуття захищеності у людей (досягнення пожежної безпеки будівель, безпека на дорогах, підтримка підприємців у кризових ситуаціях тощо), а, з іншого боку, пріоритет державних та громадських заходів щодо установ, що забезпечують фактичну особисту безпеку (підтримка систем обов'язкового персонального страхування).

Висновки. Страхова галузь має відігравати все більшу роль у забезпеченні економічної безпеки держави. Її діяльність потребує врегулювання, зважаючи на нові виклики, зокрема й пандемію. Так, пандемія коронавірусу спричинила кризу здоров'я громадян усіх країн. Окрім масштабних людських втрат та людських страждань, пандемія стала причиною масштабної економічної кризи. Криза спричинена Covid-19 продовжує негативно впливати на людей, суспільство, бізнес та економіку по всьому світу. Страхова галузь не уникнула цього впливу, але страховики швидко на неї відреагували.

Фізичні особи та підприємства зазнали великих витрат та збитків, яких могли б уникнути за наявності страхового покриття. Тому, розробка нових страхових продуктів в умовах підвищення фінансової безпеки страхового ринку стає актуальною задачею для страховиків.

Отже, страхування є визначальною складовою економічної безпеки держави й слугує інструментом захисту фізичних та юридичних осіб на комерційній основі, що формує основу капіталовкладень у галузі національної економіки.

\section{Лimepamypa:}

1. Гладчук О. М. Фінансова безпека сучасного страхового ринку України [Електронний ресурс] / О. М. Гладчук // Ефективна економіка. - 2014. - Режим доступу до ресурсу: http://www.economy.nayka.com.ua/?op=1\&z=2931.

2. Яремик М. М. Фактори впливу на фінансову безпеку страхового ринку [Електронний pecypc] / М. М. Яремик - Режим доступу до ресурсу: http://libfor.com/index.php?newsid=2479.

3. Prikazyuka N. Security of the insurance market of Ukraine and the determining factors. [Електронний ресурс] / N. Prikazyuka, T. Motashkoa // Part of special issue: 22nd International Economic Conference of Sibiu 2015, IECS 2015 «Economic Prospects in the Context of Growing Global and Regional Interdependencies». - 2015. - Режим доступу до ресурсу: http: doi:10.1016/S2212-5671(15)01001-1.

4. Управління фінансовою безпекою економічних суб'єктів : навчальний посібник для студентів вищих навчальних закладів економічних і юридичних спеціальностей усіх форм навчання / Державний вищий навчальний заклад «Українська академія банківської справи Національного банку України» ; за заг. ред. д-ра екон. наук, проф. С. М. Фролова ; [С. М. Фролов, О. В. Козьменко, А. О. Бойко та ін.]. - Суми : ДВНЗ «УАБСНБУ», 2015. - 332 с.

5. Дахнова О. С. Соціальні аспекти економічної безпеки України. / О. Є. Дахнова. // Зовнішня торгівля: право, економіка, фінанси.. - 2012. - №3. - С. 245-252.

6. Барановський О. I. Фінансова безпека в Україні (методологія оцінки та механізми забезпечення) / О. І. Барановський. - Київ: Київ. нац. торг.-екон. ун-т, 2017. - 759 с. 
7. Барановський О. I. Фінансова безпека в Україні (методологія оцінки та механізми забезпечення) / О. І. Барановський. - Київ: Київ. нац. торг.-екон. ун-т, 2004. - 759 с.

8. Сокол С.В. Страховий ринок та основні загрози його фінансовій безпеці / С.В. Сокол // Проблеми і перспективи розвитку банківської системи України. - 2012. - Вип. 34. - С. 285-290.

9. Фурман В. М. Сучасні загрози економічній безпеці вітчизняних фінансових установ (на прикладі банківських установ і страхових компаній). / В. М. Фурман, Н. В. Зачосова. // Інвестиції: практика та досвід. - 2015. - №16. - С. 7-11

10. Страхование как механизм обеспечения экономической безопасности России. [Електронний ресурс] / Э. А.Русецкая, В. А. Арустамова, Е. В. Аксененко, М. Г. Русецкий // Национальные интересы: приоритеты и безопасность.. - 2010. - Режим доступу до ресурсу: https://cyberleninka.ru/article/n/strahovanie-kak-mehanizm-obespecheniya-ekonomicheskoy-bezopasnostirossii.

11. Біла книга «Майбутнє регулювання ринку страхування» [Електронний ресурс] Режим доступу до ресурсу: https://bank.gov.ua/ua/news/all/bila-kniga-maybutnye-regulyuvannyarinku-strahuvannya.

\section{References:}

1. Hladchuk, O. M. (2014). Finansova bezpeka suchasnoho strakhovoho rynku Ukrainy [Financial security of the modern insurance market of Ukraine]. Efektyvna ekonomika - Effective economy. Retrieved from http://www.economy.nayka.com.ua/?op=1\&z=2931 [in Ukrainian].

2. Yaremyk, M. M. (n.d.). Faktory vplyvu na finansovu bezpeku strakhovoho rynku [Factors influencing the financial security of the insurance market] Retrieved from http://libfor.com/index.php?newsid=2479 [in Ukrainian].

3. Prikazyuka, N., Motashkoa, T. (2015). Security of the insurance market of Ukraine and the determining factors. Part of special issue: 22nd International Economic Conference of Sibiu 2015, IECS 2015 «Economic Prospects in the Context of Growing Global and Regional Interdependencies». DOI: $10.1016 / \mathrm{S} 2212-5671(15) 01001-1$

4. Frolov, S. M., Kozmenko, O. V., \& Boiko, A. O. (2015). Upravlinnia finansovoiu bezpekoiu ekonomichnykh subiektiv : navchalnyi posibnyk dlia studentiv vyshchykh navchalnykh zakladiv ekonomichnykh i yurydychnykh spetsialnostei usikh form navchannia [Management of financial security of economic entities: a textbook for students of higher educational institutions of economic and legal specialties of all forms of education]/ Derzhavnyi vyshchyi navchalnyi zaklad «Ukrainska akademiia bankivskoi spravy Natsionalnoho banku Ukrainy» - State Higher Educational Institution "Ukrainian Academy of Banking of the National Bank of Ukraine" . S. M. Frolova (Ed.). Sumy : DVNZ «UABSNBU» [in Ukrainian].

5. Dakhnova O. Ye. (2012). Sotsialni aspekty ekonomichnoi bezpeky Ukrainy [Social aspects of economic security of Ukraine]. Zovnishnia torhivlia: pravo, ekonomika, finansy - Foreign trade: law, economics, finance,3, 245-252 [in Ukrainian].

6. Baranovskyi, O. I. (2017). Finansova bezpeka v Ukraini (metodolohiia otsinky ta mekhanizmy zabezpechennia) [Financial security in Ukraine (evaluation methodology and support mechanisms)]. Kyiv: Kyiv. nats. torh.-ekon. un-t [in Ukrainian].

7. Baranovskyi, O. I. (2004). Finansova bezpeka v Ukraini (metodolohiia otsinky ta mekhanizmy zabezpechennia) [Financial security in Ukraine (evaluation methodology and support mechanisms)]. Kyiv: Kyiv. nats. torh.-ekon. un-t [in Ukrainian].

8. Sokol, S.V. (2012). Strakhovyi rynok ta osnovni zahrozy yoho finansovii bezpetsi [Insurance market and the main threats to its financial security]. Problemy i perspektyvy rozvytku bankivskoi 
systemy Ukrainy - Problems and prospects of development of the banking system of Ukraine, 34, 285290 [in Ukrainian].

9. Furman, V. M. (2015). Suchasni zahrozy ekonomichnii bezpetsi vitchyznianykh finansovykh ustanov (na prykladi bankivskykh ustanov i strakhovykh kompanii) [Modern threats to the economic security of domestic financial institutions (on the example of banking institutions and insurance companies)]. Investytsii: praktyka ta dosvid - Investments: practice and experience, 16, 7-11 [in Ukrainian].

10. Rusetskaia, E. A., Arustamova, V. A., Aksenenko, E. V., \& Rusetskyi, M. H. (2010). Strakhovanye kak mekhanyzm obespechenyia эkonomycheskoi bezopasnosty Rossyy. [Insurance as a mechanism for ensuring the economic security of Russia]. Retrieved from https://cyberleninka.ru/article/n/strahovanie-kak-mehanizm-obespecheniya-ekonomicheskoy-bezopasnostirossii [in Russian].

11. Bila knyha «Maibutnie rehuliuvannia rynku strakhuvannia» [White Paper "Future regulation of the insurance market"] (n.d.). bank.gov.ua. Retrieved from https://bank.gov.ua/ua/news/all/bilakniga-maybutnye-regulyuvannya-rinku-strahuvannya [in Ukrainian]. 